1 Corinthians was, I believe, compressed into some two or two and a half years which preceded its issue in 1881, the last few chapters being rather hastily finished under strong editorial pressure. The appearance of the Revised Version also gave a stimulus to his critical energies, and led to the production of several very characteristic articles in the Expositor. Thus I believe that most of the points about which he used to talk to me will have found their way into print. Among the subjects on which his views seemed most original would be: the force of the termination - $\mu a$ (see note on 1 Cor. v. 6), the force of the middle voice as never directly reflexive (1 Cor. vi. 11 , cf. $\mathrm{x}$. 2 ), the uses of iva (1 Cor. vii. $29-31$; ef. Expositor, 2nd ser., vol. iii., 1882, p. 455ff.), $\ddot{\omega} \sigma \tau \epsilon$ with infin. (ibid. p. 3ff.), participial tenses (ibid. p. 161ff.), $\epsilon^{*} \gamma \epsilon \epsilon$ (ibid. 176f.); but all the uses of the particles he seemed to have thoroughly fathomed.

At the present time it is not necessary to say much about the Commentary. The judicious reader will not go to it for that which he will not find; but he will find (especially in the first ten chapters) the most searching grammatical exegesis, inspired by profound knowledge of Greek, and expressed in language singularly plastic to shades of meaning, and rising through all its apparent quaintness to passages of striking lucidity and force. It was a fresh and independent Commentary, a product of pure English thought and training, if ever there was one.

About the same time (in 1882) was published a Latin poem, The Nihilist in the Hayfield, the contents of which corresponded to the curious juxtaposition in the title. It was an extraordinary tour de force. The metrification was marvellous, and rivalled Virgil himself in the elaborately studied variation and surprises of cadence and rhythm. It had sometimes even more than Virgilian strength, but rather less than the Virgilian delicacy of touch, and a certain broad humour which could not be called Virgilian. I should prefer to quote as a specimen of the author's powers a translation of Tennyson's epitaph to Sir John Franklin, written, I believe, in response to an invitation addressed to a number of our leading scholars but, if $I$ am not mistaken, too late to be printed along with the rest. I quote the lines from memory.

Non habet hoc marmor tua, navita nobilis, ossa ; Albens Arctos habet, perpetuaeque nives.

Non mare sed caelum nunc tranas umbra, polumque Sidereum carsu prosperiore petis.

Whatever justice description may do to the works, it cannot do justice to the man-to that transparent simplicity of character along with the flashes of insight to which such simplicity is often allied; to the oldfashioned politeness beautiful to see because it sprang from genuine kindliness of heart; to his equally old-fashioned and unaffected piety : and to all those lovable oddities of habit and manner which must have sorely tried the patience of those who were responsible for the due and exact performance of his public duties, but which only helped to endear him to all whom he met in any other relation, and which made him the hero of so many delightful stories. Just one such story I must allow myself to tell. It concerns one who is associated with me in these remarks. All the world knew what a stumbling-block mathematics had been to the young scholar in his University career. $\mathrm{He}$ took his revenge by a peculiar fondness for mathematical diction and for little feats of mathematical gymnastics. He was discoursing to me once on the value which he attached to the signs of real originality, and he exemplified this by a paper on the Epistle to the Philippians which he had set at Rugby. It was generally well done. ' $I$ gave $A$. four hundred and twenty, and $B$. four hundred and fifty marks out of five hundred. And what do you think I gave S. ? I gave him seven hundred marks out of five!' We were walking in the cloisters at Durham, and I can remember as if it were only yesterday the way in which he suddenly wheeled round in front of me, beaming all over at his own joke, and broke into a peal of laughter which must have startled the worshippers (if there were any, as very possibly there were) inside.

W. SANDAY.

[We are glad to learn that a selection from Canon Evans' compositions in Greek, Latin, and English will shortly be published,-ED.]

\title{
JOHN HENRY ONIONS, M.A.
}

Mr. J. H. Onions was born in 1852 , educated at Shrewsbury, and in 1871 came up to Christ Church, Oxford, as a Junior
Student. His University distinctions, first class in the Honour School of Moderations 1873, Ireland Scholarship 1875, second class 
in Literis Humanioribus and Craven Scholarship 1876, gave promise of a brilliant future. In the same year he was elected to a Senior Studentship at Christ Church, at which college he remained, with a short interval of study under Prof. Buicheler at Bonn, as a Student and Tutor until his death, which took place on Wednesday May 22 in his college rooms after a short illness.

As a teacher Mr. Onions was very successful. Patient and careful, he possessed also the rarer faculty of kindling interest and enthusiasm; many of his old pupils can testify that it was through him their minds were first turned to serious study. He had a most retentive memory, and carried much of his knowledge in his head; from which it unfortunately results that he has left few papers behind. He wrote Latin easily and with idiomatic force. Mr. York Powell tells me that on one occasion when he had to make the annual Latin speech to the Curators of the Bodleian, after writing his speech in English, he asked Mr. Onions to translate it into Latin in the style of the Silver Age. Mr. Onions at once complied, and read it off with hardly a moment's hesitation into excellent Latin of the kind desired.

As a scholar he was sound, acute, learned, enthusiastic. For the last seven years he had devoted his leisure to the preparation of an edition of Nonius Marcellus, De Compendiosa Doctrina, at which he worked with dogged determination, spending some part at least of every holiday in the collation of MSS. His edition was nearly complete when he was overtaken by death; some specimen sheets were already in type; and he had collated all the important MSS., except one at the Escorial, which he hoped to have examined this summer. His faculty of minute observation, combined with his industry, his wide and exact knowledge of Latin literature, his acuteness and quiet enthusiasm for his subject, justify the belief that, had he lived long enough to complete it, his Nonius would have been one of the most solid achievements of English scholarship. Fortunately the greater part of the work is done, and has been entrusted, by his own wish, to $\mathrm{Mr}$. Lindsay to publish as nearly as possible as he left it, only adding a collation of the Escorial MS. His original design was an edition embracing both an apparatus criticus and a commentary; the commentary was to have been the joint work of himself and Professor Nettleship, who had handed over his notes to Mr. Onions. But for the present the commentary was postponed, and the critical edition was to have appeared as soon as possible. He began his work on Nonius by a new collation of the Harleian MS. 2719, which had not before been collated throughout. This was published by the Clarendon Press in 1882, and attracted much attention in Germany (see e.g. Baehrens, Fragmenta poetarum Romanorum, p. 4). I remember a few years ago buying for him from a German bookseller a copy of Mercier's Nonius. When it arrived it contained the autograph of Georges, who had written on the fly-leaf some complimentary remarks about $\mathrm{Mr}$. Onions' own book.

His arrangement of the MSS. of Nonius (as far as we have it imperfectly set forth in the scattered papers which he has published) shows an unusual power of grappling with the classification of MSS. Few whose experience of MSS., those tantalising relics of antiquity, and the endless puzzles they present, has not been acquired at first hand, can appreciate how much he must have laboured and thought, before the mass of materials could be induced to assume that harmonious scientific order which it bears under his hands. Nor was his interest in textual criticism confined to Nonius. He lent me a short time ago the Quaestiones criticae et palaeographicae de vetustissimis codiciöus Livianis of W. Heräus (Berlin, 1885), telling me that he considered it, though unambitious in form, one of the most instructive books upon that subject; and whoever reads it will, I am sure, endorse his opinion.

of his numerous contributions to the Journal of Philology the larger part are directly or indirectly concerned with Nonius, showing how uniformly he kept his attention upon his author. They are: vol. xi. p. 75ff., Notes on Placidus, Gellius, Nonius (the foretaste of his studies of the Harleian MS.); vol. xii. p. 77ff., Continuation of the same paper; p. 90 , Notes on Verg. Aen. I. 18, Petronius 43, Plautus Most. 142 ; vol xiv. p. 53ff., Notes chiefly on the Menaechmi of Plautus: appended is a note on Propertius I. 21, which resulted in a small controversy with Mr. Postgate, p. 289, and vol. xv. p. 152ff.; Ibid. p. 165ff., Notes on Plautus Mercator: p. 167ff., Notes on Placidus; vol. xvi. p. I61ff., Notes on Nonius; vol. xvii. p. $289 f$., Notes on Tacitus, Histories. To the Classical Review he contributed in Vol. i. 304 a review of Schöll's ed. of the Captivi and Rudens of Plautus, p. 242 a note on the 17th Epode of Horace, in vol. ii. 23 a review of Sloman's Phormio; also two searching criticisms of the two volumes of Lucian 
Miuller's Nonius (vol. ii. p. 314 and in the present number), besides a paper of emendations upon Nonius in the last June number. In Professor Nettleship's Lectures and Essays on subjects connected with Latin Literature and Scholarship, p. 295ff. will be found some notes upon Nonius furnished by $\mathrm{Mr}$. Onions.

Though depressed at times, he was usually cheerful, and talked readily about his own work or any other subject. He had a fund of quiet humour to which the usual gravity of his countenance lent greater piquancy. Those who knew him personally have to mourn a friend who was warm-hearted, honest, and unassuming; those who knew him only through his writings must feel that in him England has lost a scholar of no ordinary promise, and more than ordinary performance.

S. G. OWEN.

\section{HENRY WILI.IAM CHANDLER.}

By the death of $H$. W. Chandler Oxford loses a scholar of a kind which is every day becoming rarer in our modern Universitiesa man of unique attainments and great intellectual power whose life was one long devotion to learning. ' The few are now fewer' was what he said when Pattison died; and we may with good reason say the same again now that he too has left us.

The story of his life is soon told. Born in London in 1828, he entered Pembroke College as a commoner in 1848 ; became a scholar of his College (in succession to the late George Rolleston) in 1851, and a fellow in 1853, having taken a 'First' in Literae Humaniores in the preceding year. In 1867 he succeeded his friend Mansel as Waynflete Professor of Moral and Metaphysical Philosophy. In 1884 he became one of the Curators of the Bodleian, and, if he is at all known to the world, I suppose it is in connexion with the 'Bodleian question.' Regarding the Bodleian as the one remaining institution that represented the best traditions of the University, he thought it a matter of duty to come forth from his retirement and do what in him lay to keep the library intact.

Chandler was never at any public school ; when he came up to Oxford at the age of twenty he was, as far as the ordinary subjects of academical education are concerned, a self-educated man, but on the other hand he had already a very considerable experience of books and, what is more, he knew how to use them. As a boy, through the kindness of a friend, the then keeper of the Guildhall library, he had had the run of fine library, where he revelled in books and Learnt the great art of reading for himself. Wheh training or want of training however, though it may be conducive to intellectual independence, has certain obvious disadvantages, if one has to enter the race for
University distinctions. As an undergraduate, Chandler was not thought 'strong in scholarship.' He was accordingly sent to read with a scholarship 'coach,' the learned and eccentric Hyman of Wadham, whose name is saved from oblivion by the generous recognition of his merits in Pattison's Memoirs. Whether he also read with Mansel I cannot discover; but he certainly came quite early under his influence, and in after life he always spoke of Mansel in a way which showed how strong this influence must have been.

After taking his degree Chandler in a very short time found himself with an established reputation as an Aristotelian scholar; and for several years he was the great 'coach,' to whom most of the best undergraduates resorted for light and instruction in the 'Ethics.' 'Those who enjoyed the privilege of thus reading with him are unanimous on one point-his excellence and success as a teacher. It was indeed no small thing to be brought into personal contact with one who knew as well as taught his subject, one familiar with the whole of Aristotle, and gifted with a power of logical analysis and interpretation such as is rarely found in us feeble moderns. But Chandler besides his knowledge had a real genius for getting at men's minds and making them think things out for themselves. 'He made us think' is what one of his pupils says of him, and there is surely no higher praise than this.

He was in a sense a born Aristotelian. Aristotle was to him something more than an important moment in the history of thought; his philosophy was in its aims and method the type and model of what a philosophy should be. His attitude therefore as an Aristotelian scholar was somewhat peculiar. Though familiar enough with modern critical views and theories as 